\title{
Evaluating The Projection Of Corporate Culture Online
}

Roblyn Simeon, San Francisco State University, USA

\begin{abstract}
It is argued that corporate culture projection should be considered an important business strategy and a crucial factor in entering different business environments. The framework presented in this paper is based on an extension of the AIPD web evaluation model (attracting, informing, delivering, positioning) to a greater focus on a firms' stakeholders. Using this framework, the paper presents an empirical investigation of web organization and content of sites in three countries. The website evaluations and statistical analyses support the idea that websites can consistently project an appealing corporate culture if web content is structured with stakeholders in mind.
\end{abstract}

Keywords: AIPD, online corporate culture, cross-border web strategy

\section{INTRODUCTION}

$\mathscr{J}$ he concept of corporate culture has been linked to many business strategies. Corporate culture consists of the public image as well as the internal social environment that results from the interaction of a firm's characteristics, values, expectations, staff profile, and business strategies (Pettigrew 1979; Fitzgerald 1988; Denison 1990; Schein 1991). The idea that a company's culture can have a significant impact on its behavior and performance is a widely held view and many researchers continue to apply this perspective in organizational studies (Bloor 1994; Denison and Mishra 1995; Harris and Ogbonna 2002). These wide ranging studies showed that corporate culture can have an impact on areas such as employee recruitment, organizational commitment, workflow management, innovation, negotiation strategies, brand recognition, community relations, alliance behavior and organizational learning (Argyris 1978; Gudykunst, Matsumoto et al. 1996; Homburg and Pflesser 2000; Adair, Okumura et al. 2001; Aladwani and Palvia 2002; Dunkerley and Robinson 2002; Evans and Mavondo 2002; Harris and Ogbonna 2002).

Although internet sites represent unique virtual locations, the world-wide web exists because of the global use of standardized technologies and practices. Consequently, initial studies centered on the best practices for the effective use of web design and structure to inform and communicate (Betts 1995; Fink and Laupase 2000; Aladwani and Palvia 2002; Ranganathan and Ganapathy 2002). There was every expectation that this standardized technology infrastructure would minimize the impact of cross-cultural forces. However, instead of complete convergence, we have witnessed an increasing variety of approaches as organizations from different national environments establish their presence in this virtual arena. In response, a number of consultants and researchers have resorted to using various cultural values approaches to examine the impact of culture on websites in different national environments. Unfortunately, they still have not provided a consistent approach for understanding how firms can manage their web content to develop and effectively project their corporate culture online and across national boundaries. In fact, most of the research on consistent web strategies has focused on the effective use of web design and web tools (Hernon 1998; Bauer and Scharl 2000; Marcus 2003; Robbins and Stylianou 2003).

This paper will present a framework that allows for a consistent approach to evaluating the projection of corporate culture online. A key aspect of this framework is the strategic approach to presenting website content. The paper takes the view that presenting a consistent corporate web culture across borders can give strategic advantages to international firms. In effect, creating and projecting a consistent corporate identity can also be considered an essential strategic mode of entry into foreign environments. 
The framework to be presented is based on an extension of the AIPD web evaluation model (attracting, informing, delivering, positioning) to a greater focus on firms' being responsive to stakeholders (Simeon 1999; Simeon 2001). The paper will provide empirical support for the suggested framework by evaluating information that was collected from 350 corporate websites in three countries. Statistical analyses were used to confirm the usefulness of this approach in identifying content factors that support the emergence of positive corporate web culture characteristics.

\section{LITERATURE REVIEW OF FACTORS IMPACTING THE PROJECTION OF WEB CULTURE}

The concern with web design and culture projection has been examined from a number of different perspectives. Interest in the different approaches has been shifting as the internet evolves from merely a communication tool to a more virtual interactive environment. Figure 1 below illustrates how the strategic use of web content has evolved.

Figure 1: The Evolution of the Strategic Use of the Web

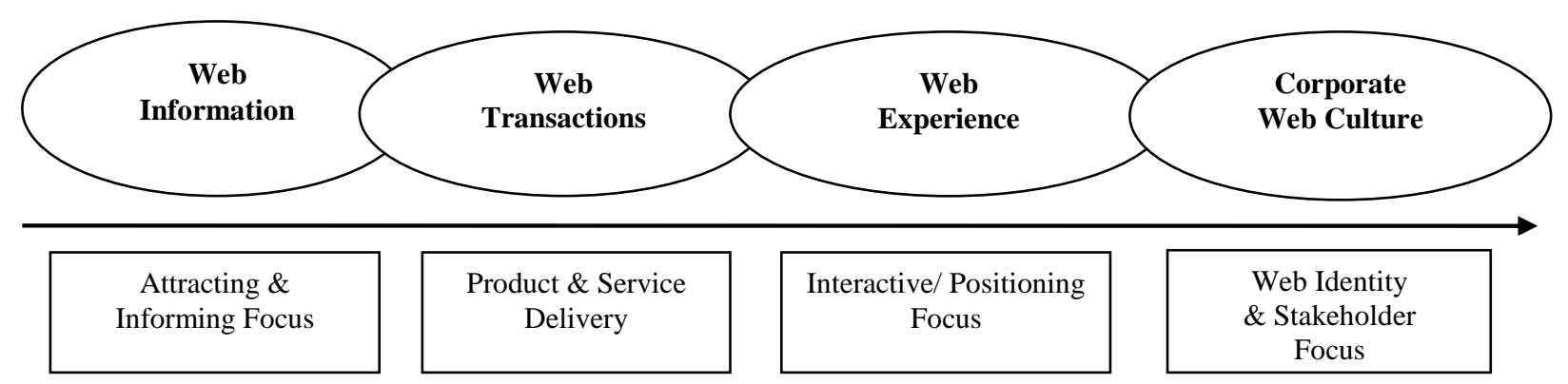

There has been a progressive blurring of the distinction between external and internal culture as the impact of the internet is felt inside and outside organizations as well as across many national boundaries. The summaries of the perspectives below show the evolution of the interest in and use of culture in web strategy.

\section{Impact of Intranet \& Extranet Usage on Corporate Culture}

This perspective highlights the impact of extensive intranet usage (intra-firm web) on the overall culture of the organization. Since the intranet refers to the application of the internet within an organization for the private purposes of its members, many studies show how this new technology forces firms to reorganize their operations and change their approach to information sharing. Organizations extensively using intranets have had to adopt a new degree of openness, accessibility and cooperation to the extent that the internal culture of the firm was irrevocably changed (Borsook 1995; Grochow 1996; Hibbard 1998; Gray 1999). Since many firms rapidly expanded their web environment to their customers, suppliers and affiliates, extranets (external web interfaces between suppliers \& customers) also had an impact on business culture. This fast and open communication environment transformed many firms' attitude toward their business partners and customers. Studies show that firms that actively participated in a networked internet environment or in e-commerce activities had to adjust their management style and business processes in ways that eventually changed their corporate culture (Croft 1995; Taylor 1997; Cairncross 2000; Chabrow 2000).

\section{Cultural Values Impacting Perception, Web Design and Usage}

This perspective represents a recently popular approach to studying the impact of culture on web activities. The majority of its proponents use Hoftstede's value dimensions to examine differences in preferences, web design, and communication style across cultures (Robbins and Stylianou 2001; Marcus 2003). The main assumption is that 
the dominant national culture will directly or indirectly affect the way websites are displayed, perceived, and appreciated by managers, staff, and consumers. Cultural dimensions such as individualism, uncertainty avoidance, power distance, masculinity and time orientation are often correlated with different design, communication and transaction styles of websites around the world (Gudykunst 1998; Fink and Laupase 2000; Tang 2001). The drawback with this approach is the observation that sometimes the within-country differences in websites are sometimes greater than cross-border differences. The nature of the firm and the type of sector may better explain some web design and customer perception differences.

\section{Ethnic Sites, Pop Culture and Web Community Environments}

Another approach to exploring online culture is the examination of sites that are linked to ethnic groups, pop culture events, and virtual web communities. The study of websites linked to ethnic groups and institutions show that it is crucial for these sites to have the capability of displaying multiple languages, unique designs, color schemes and music preferences for communities spread over space and time. In a sense, the specialized interests of the ethnic groups and special interests drive the cultural dimension of these sites (Lam 1997; Tang 2001; Cunliffe, Jones et al. 2002). The strong presence of pop culture sites and virtual web communities can be attributed to their ties to important events or social preferences (facebook.com, myspace.com, forumfind.org, \&other online communities). Here also, it is the strong and persistent interests, preferences and interaction of the users that create a cultural dimension on these websites (Kuchinskas 1999; Williams 1999; Pack Jun 2001). However, unlike web communities serving narrow interests, corporations operating in a competitive business environment need to serve a variety of stakeholders.

\section{ADAPTING THE AIPD FRAMEWORK FOR ONLINE CULTURE PROJECTION ANALYSIS}

\section{The AIPD Stakeholder Approach}

This perspective is a combination of two strategic views. One focuses on the structuring of web content (AIPD) and the other focuses on the target of the web content. The AIPD perspective takes the view that the strategic ways in which activities are presented on websites can have a definite impact on an organization's image, culture, and web performance. The AIPD (attracting, informing, delivering \& positioning) framework focuses on the structuring of web capabilities and content in a systematic way to develop virtual branding (Simeon 1999; Simeon 2001). In this perspective, an organization can transform its virtual space into a recognizable location by effectively managing website images, content, and structure (figure 2).

Figure 2: The AIPD Perspective

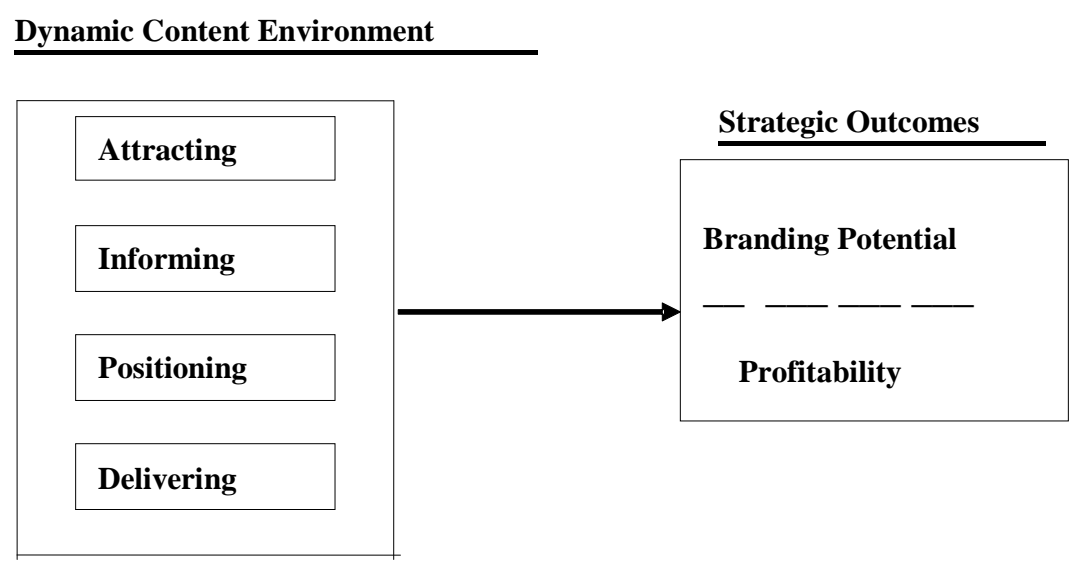

Source: (Simeon, 2001) 
The second perspective that focuses on stakeholder targeting sees organizational identity as being embedded in a network of relationships. It holds the view that the dynamic interaction of a firm with its internal and external stakeholders drives the development of its corporate culture. There is also the assertion that a firm can consciously manage internal interaction and external perceptions in ways that boosts its image in the community and marketplace (Hornick 1998; Scott and Lane 2000; Violino 2000; Zimmerman 2000; Lewis Oct/Nov 2000).

The combined approach is henceforth referred to as the AIPD Stakeholder approach (figure 3). This approach assumes that in order to project its corporate culture, firms will develop and then project positive and desirable images, characteristics, and capabilities of the organization on their websites. They do this by effectively structuring the web content to respond to attract a wide variety of stakeholders. The combined perspectives underlie the framework presented below (Borsook 1995; Marken 1996; Patrick 1997; Homburg and Pflesser 2000; Kabanoff and Daly 2000; Dunkerley and Robinson 2002).

Figure 3: AIPD Stakeholder Framework for Corporate Culture Projection

Dynamic Content Environment

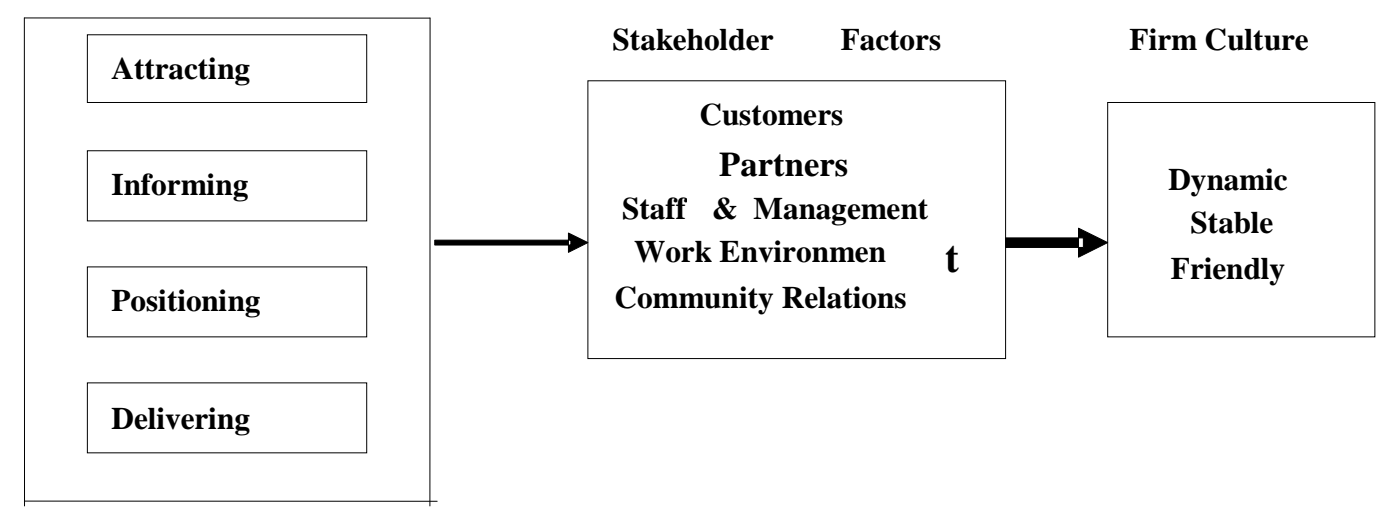

It is clear that all web cultures interact with or target stakeholders to some extent. Stakeholders, here, can be separated into four main categories: customers, affiliates, employees, investors/ community. It is our claim that the manner in which firms address stakeholder interests helps to create the virtual infrastructure upon which the corporate culture can be built. Consequently, the differences in the way the corporate web culture is perceived will depend on which aspects of stakeholder interests are stressed and which ones are downplayed (Gaffin 1994; Hibbard 1998; Zhou and Nakamoto 2001).

Hypothesis I: The more extensive and targeted the stakeholder related web information, the more likely it will be for firms to successfully project positive corporate culture characteristics.

Hypothesis II: The more dynamic the organization of the website, the more positive will be the perception of the corporate web culture.

\section{METHODOLOGY AND DATA COLLECTION}

The information for this project was gathered from corporate websites in three different countries (Japan, U.S.A \& U.K.). The list of companies represents a random selection of well-known firms in each country (appendix, table 5). The AIPD Stakeholder framework was used to identify the type and pattern of information gathered. To that end, we examined the extent to which explicit stakeholder related information was presented on each corporate website (table 3, appendix ). We also collected information on the web tools and the web organization of the sites. 
In order to evaluate the projection of corporate culture it was necessary to capture and code the perception of those accessing the websites. For each country we used two individuals for separate perception related tasks. One individual collected and coded stakeholder related information. The other individual thoroughly explored the websites and then graded them on the extent to which they projected corporate cultural characteristics such as dynamic, stable, and friendly. The individuals who coded the websites were of the same nationality as the website locations. In this way, we minimized potential cross cultural bias connected with evaluating sites in different national environments.

The positive corporate cultural characteristics studied (dynamic, stable \& friendly) have frequently been mentioned as desirable characteristics for firms operating in competitive environments. These projected characteristics identify the firm's positive image in the community and the marketplace (Gordon and Ditomaso 1992; Denison and Mishra 1995; Deshpande, Farley et al. 2000; Homburg and Pflesser 2000).

We used a number of statistical techniques to examine the projection of corporate culture. First, we used the ANOVA procedure to compare variable means across the three countries studies. We then used regression analysis to examine the impact of stakeholder related factors on the desired projected corporate cultural characteristics. For scales used in all the analyses we carried out reliability analysis to determine the cronbach alphas. Tables $3 \& 4$ (appendix) give a detailed listing of the questions, the variables and the scales used in the analyses below

\section{Dependent Variables}

Dynamic Company (Scale)

This scale is a combination of three variables. On a scale from $1-5$, it measures the extent to which this website projects the company as: 1) innovative, 2) flexible, and 3) global. The Cronbach alpha was .72 (table 4).

Stable Company (Scale)

This scale is a combination of two variables. On a scale from $1-5$, it measures the extent to which this website projects the company as: 1) stable and 2) a leader. The Cronbach alpha was .82 (table 4).

Friendly Company (Single Variable)

This is the extent to which (1-5 scale) the website projects the company as being friendly (table 3 ).

Strong Online Corporate Culture (Scale)

The objective of this scale was to capture an overall projection of corporate culture on the website. This scale combines all of the six individual variables used in the previous three dependent variables. The Cronbach alpha was .84 (table 4).

\section{Independent Variables}

Effective Web Tools (Scale)

An average of the presence or absence $(0,1)$ of five basic web practices on the site: 1) can submit resumes on-line, 2) links to other company locations, 3) links to affiliates or partners, 4) photos of employees on-line, and 5) profile of top executives on-line. The Cronbach alpha $=.60$ (table 4$)$.

Good Web Organization (Individual Variable)

This variable measures the extent to which (1-5 scale) the website appears well organized. This is generally influenced by web design, technology and cultural preferences (table 3 ). 
Dynamic Staff (Scale)

This scale combines seven variables that are related to internal stakeholders (staff \& management), the extent to which the websites presents positive images and writes about: 1) creative \& innovative employees, 2) staff with initiative and judgment, 3) dependable and hard-working staff, 4) good problem solvers, 5) excellent leadership skills, 6) good staff diversity, and 7) internationally-oriented employees. The Cronbach alpha =.91 (table 4).

\section{Good Staff Development (Scale)}

This scale is related to staff development, the extent to which: 1) exciting career opportunities exist and 2) there is investment in staff development. The Cronbach alpha $=.74$ (table 4).

\section{Good Work Environment (Scale)}

This is a two-variable scale, the extent to which: 1) there is a group-oriented workplace and 2) the company has a fun or dynamic workplace. The Cronbach alpha $=.81$ (table 4 ).

\section{Good Customer Focus (Scale)}

This seven-variable scale is related to product and service-related activities, the extent to which the company mentions: 1) unique products or services, 2) innovative products/services, 3) excellent quality, 4) dependable services/products, 5) good customer support, 6) quick and convenient service, and 7) popular services and products. The Cronbach alpha $=.84$ (table 4 ).

\section{Subsidiary \& Partner Focus (Scale)}

This four-variable scale is related to external stakeholders, the extent to which the company writes about: 1) strong partnerships, 2) extensive business networks, 3) flexible alliances, and 4) cooperative relations. The Cronbach alpha $=.89($ table 4$)$.

\section{Good Community Linking Behavior (Scale)}

This two-variable scale is related to external community stakeholders, the extent to which the company writes of: 1) committment to serving the community and 2) having high staff-community interaction. The Cronbach alpha $=.90$ (table 4).

Image of a Leading Firm (Scale)

This three-variable scale is related to market status of the firm, the extent to which there is discussion of: 1) the firm as a market leader, 2) the company as a global organization, and 3) the company has an extensive history online. The Cronbach alpha $=.63($ table 4$)$.

\section{Performance Focus Firm (Scale)}

This three-variable scale is linked to investor concerns (external stakeholders), the extent to which: 1) the company is proud of its performance, 2) the firm's vision is to excel and grow, and 3) the company is using responsive strategies. The Cronbach alpha $=.71$ (table 4 ).

\section{Dummy Variables}

US, UK. Japan is the reference factor $($ Japan $=0)$. 


\section{ANALYSIS AND DISCUSSION}

\section{Comparison of Means}

We first examined the differences across countries in the means of the variables \& scales (table1). For the U.S.-Japan comparison, American firms not only had higher means for most stakeholder related factors, the differences were statistically significant. Japanese companies had a higher mean for community stakeholder linking activities. For the U.S.-U.K. comparisons, American firms showed significantly higher means for all factors except one. Like Japan, the British firms also had a higher mean for community related activities. For the Japan-U.K. comparison, there was no statistical difference for the usage of two factors: web tools and the image of as stable leading firm. Although Japanese firms recorded higher means for community related activities, British firms showed higher means for all remaining factors.

Table 1: Comparisons of Means (ANOVA)

\begin{tabular}{|c|c|c|c|c|c|c|}
\hline Means (Stdvd) & US & Japan & US & UK & Japan & UK \\
\hline Effective Web tools & $\begin{array}{c}\mathbf{3 . 5 1} \\
(1.29)\end{array}$ & $\begin{array}{c}\mathbf{2 . 5 3} * * * * \\
(1.02)\end{array}$ & $\begin{array}{c}\mathbf{3 . 5 1} \\
(1.29)\end{array}$ & $\begin{array}{c}\mathbf{2 . 5 3} * * * * \\
(1.60)\end{array}$ & $\begin{array}{c}\mathbf{2 . 5 3} \\
(1.02)\end{array}$ & $\begin{array}{l}\mathbf{2 . 5 3 +} \\
(1.60)\end{array}$ \\
\hline Web Organization & $\begin{array}{c}3.99 \\
(1.08)\end{array}$ & $\begin{array}{c}\mathbf{2 . 7 9} * * * \\
(.883)\end{array}$ & $\begin{array}{c}\mathbf{3 . 9 9} \\
(1.08)\end{array}$ & $\begin{array}{c}\mathbf{3 . 4 7} * * * \\
(1.19)\end{array}$ & $\begin{array}{c}\mathbf{2 . 7 9} \\
(.883)\end{array}$ & $\begin{array}{c}\mathbf{3 . 4 7} * * * \\
(1.19)\end{array}$ \\
\hline $\begin{array}{l}\text { Dynamic } \\
\text { Staff }\end{array}$ & $\begin{array}{l}\mathbf{2 3 . 9 8} \\
(7.46)\end{array}$ & $\begin{array}{l}15.10 * * * * \\
(5.58)\end{array}$ & $\begin{array}{l}\mathbf{2 3 . 9 8} \\
(7.46)\end{array}$ & $\begin{array}{l}\mathbf{1 9 . 8 9} * * * * \\
(7.10)\end{array}$ & $\begin{array}{l}\mathbf{1 5 . 1 0} \\
(5.58)\end{array}$ & $\begin{array}{l}\text { 19.89**** } \\
(7.10)\end{array}$ \\
\hline Good Staff Development & $\begin{array}{c}\mathbf{7 . 0 3} \\
(2.20)\end{array}$ & $\begin{array}{c}\mathbf{3 . 7 9} * * * * \\
(1.76)\end{array}$ & $\begin{array}{c}\mathbf{7 . 0 3} \\
(2.20)\end{array}$ & $\begin{array}{c}\mathbf{5 . 5 6} * * * \\
(2.41)\end{array}$ & $\begin{array}{c}3.79 \\
(1.76)\end{array}$ & $\begin{array}{c}\mathbf{5 . 5 6} * * * * \\
(2.41)\end{array}$ \\
\hline Good Work Environment & $\begin{array}{c}\mathbf{7 . 0 5} \\
(2.40)\end{array}$ & $\begin{array}{c}3.24 * * * \\
(1.29)\end{array}$ & $\begin{array}{c}\mathbf{7 . 0 5} \\
(2.40)\end{array}$ & $\begin{array}{c}\mathbf{5 . 8 6} * * * * \\
(2.30)\end{array}$ & $\begin{array}{c}3.24 \\
(1.29)\end{array}$ & $\begin{array}{c}\mathbf{5 . 8 6} * * * * \\
(2.30)\end{array}$ \\
\hline Good Customer focus & $\begin{array}{l}\mathbf{2 6 . 9 7} \\
(5.96)\end{array}$ & $\begin{array}{c}21.33 * * * * \\
(4.19)\end{array}$ & $\begin{array}{l}\mathbf{2 6 . 9 7} \\
(5.96)\end{array}$ & $\begin{array}{c}\mathbf{2 4 . 4 3} * * * * \\
(5.78)\end{array}$ & $\begin{array}{l}\mathbf{2 1 . 3 3} \\
(4.19)\end{array}$ & $\begin{array}{c}\mathbf{2 4 . 4 3} * * * \\
(5.78)\end{array}$ \\
\hline Good Subs \& partner focus & $\begin{array}{l}\mathbf{1 3 . 7 7} \\
(4.39)\end{array}$ & $\begin{array}{c}\mathbf{9 . 4 0} * * * * \\
(4.62)\end{array}$ & $\begin{array}{l}\mathbf{1 3 . 7 7} \\
(4.39)\end{array}$ & $\begin{array}{c}\text { 12.10**** } \\
(4.33)\end{array}$ & $\begin{array}{c}9.40 \\
(4.62)\end{array}$ & $\begin{array}{c}\text { 12.10**** } \\
(4.33)\end{array}$ \\
\hline Community Linking & $\begin{array}{c}\mathbf{6 . 7 7} \\
(2.74)\end{array}$ & $\begin{array}{l}\mathbf{7 . 0 7 +} \\
(1.94)\end{array}$ & $\begin{array}{c}\mathbf{6 . 7 7} \\
(2.74)\end{array}$ & $\begin{array}{c}\mathbf{5 . 3 2} * * * * \\
(2.64)\end{array}$ & $\begin{array}{c}\mathbf{7 . 0 7} \\
(1.94)\end{array}$ & $\begin{array}{c}\mathbf{5 . 3 2} * * * \\
(2.64)\end{array}$ \\
\hline Image of a Leading firm & $\begin{array}{l}\mathbf{1 1 . 3 9} \\
(3.05)\end{array}$ & $\begin{array}{c}\mathbf{9 . 0 7} * * * \\
(2.59)\end{array}$ & $\begin{array}{l}\mathbf{1 1 . 3 9} \\
(3.05)\end{array}$ & $\begin{array}{c}\mathbf{9 . 8 3} * * * \\
(3.28)\end{array}$ & $\begin{array}{c}9.07 \\
(2.59)\end{array}$ & $\begin{array}{l}\mathbf{9 . 8 3 +} \\
(3.28)\end{array}$ \\
\hline Stress Performance & $\begin{array}{l}\mathbf{1 1 . 8 9} \\
(2.60)\end{array}$ & $\begin{array}{c}\mathbf{9 . 5 1} * * * * \\
(2.71)\end{array}$ & $\begin{array}{l}\mathbf{1 1 . 8 9} \\
(2.60)\end{array}$ & $\begin{array}{c}10.49 * * * \\
(2.86)\end{array}$ & $\begin{array}{c}\mathbf{9 . 5 1} \\
(2.71)\end{array}$ & $\begin{array}{c}10.49 * \\
(2.86)\end{array}$ \\
\hline Dynamic Firm & $\begin{array}{l}\mathbf{1 0 . 9 8} \\
(2.91)\end{array}$ & $\begin{array}{c}\mathbf{7 . 6 3} * * * * \\
(2.41)\end{array}$ & $\begin{array}{l}\mathbf{1 0 . 9 8} \\
(2.91)\end{array}$ & $\begin{array}{c}\mathbf{9 . 2 6} * * * * \\
(2.79)\end{array}$ & $\begin{array}{c}\mathbf{7 . 6 3} \\
(2.41)\end{array}$ & $\begin{array}{c}\text { 9.26**** } \\
(2.79)\end{array}$ \\
\hline Global Firm & $\begin{array}{c}\mathbf{8 . 0 8} \\
(1.93)\end{array}$ & $\begin{array}{c}\mathbf{4 . 7 6}^{* * * *} \\
(1.42)\end{array}$ & $\begin{array}{c}\mathbf{8 . 0 8} \\
(1.93)\end{array}$ & $\begin{array}{c}\mathbf{6 . 8 3} * * * * \\
(2.07)\end{array}$ & $\begin{array}{c}\mathbf{4 . 7 6} \\
(1.42)\end{array}$ & $\begin{array}{c}\mathbf{6 . 8 3} * * * * \\
(2.07)\end{array}$ \\
\hline Friendly Co. & $\begin{array}{c}\mathbf{3 . 1 4} \\
(1.35) \\
\end{array}$ & $\begin{array}{c}1.67 * * * \\
(.989)\end{array}$ & $\begin{array}{c}\mathbf{3 . 1 4} \\
(1.35)\end{array}$ & $\begin{array}{c}\mathbf{2 . 6 2} * * * \\
(1.20)\end{array}$ & $\begin{array}{c}1.67 \\
(.989)\end{array}$ & $\begin{array}{c}\mathbf{2 . 6 2} * * * \\
(1.20)\end{array}$ \\
\hline Strong online Culture & $\begin{array}{l}22.21 \\
(5.22)\end{array}$ & $\begin{array}{c}\text { 14.06**** } \\
(2.76)\end{array}$ & $\begin{array}{l}\mathbf{2 2 . 2 1} \\
(5.22)\end{array}$ & $\begin{array}{c}\mathbf{1 8 . 7 1} * * * * \\
(5.19)\end{array}$ & $\begin{array}{l}\mathbf{1 4 . 0 6} \\
(2.76)\end{array}$ & $\begin{array}{c}18.71 * * * * \\
(5.19)\end{array}$ \\
\hline $\mathrm{N}=$ & 142 & 70 & 142 & 145 & 70 & 145 \\
\hline
\end{tabular}

This examination of the means for the scales show that firms in all three countries generally present stakeholder related factors on their websites. However, there is a range in the extent to which these practices are consistently used. For most of the scales, American firms rank first, British firms second and Japanese firms third in the use of these factors.

\section{Regression Analysis}

The results of the regression analysis (table 2) show that stakeholder related content consistently impacts the perceived corporate cultural characteristics of the websites. We examined firm characteristics such as dynamic, 
stable, and friendly. We also combined these dependent variables into an overall strong web culture scale. Except for staff development activities, all the stakeholder content factors had a significant impact on at least one dependent variable. Moreover, both internal and external stakeholder factors played a significant role in boosting the perception of corporate web culture characteristics. The discussion below of the significant factors provides additional insights into the link between stakeholder content and corporate web culture.

Table 2: Regression Analysis - Projected Corporate Culture

\begin{tabular}{|c|c|c|c|c|c|c|c|c|}
\hline $\begin{array}{l}\text { Stakeholder } \\
\text { Factors }\end{array}$ & $\begin{array}{l}\text { Dynamic } \\
\text { Culture } \\
\text { Projected }\end{array}$ & (SE) & $\begin{array}{c}\text { Stable } \\
\text { Firm } \\
\text { Projected }\end{array}$ & (SE) & $\begin{array}{c}\text { Friendly } \\
\text { Culture } \\
\text { Projected }\end{array}$ & (SE) & $\begin{array}{l}\text { Strong } \\
\text { Online } \\
\text { Culture } \\
\end{array}$ & $(\mathrm{SE})$ \\
\hline Web tools & .140 & .073 & $\begin{array}{l}.00406 \\
\end{array}$ & .054 & .00007 & .044 & .00969 & .108 \\
\hline $\begin{array}{l}\text { Good web } \\
\text { organization }\end{array}$ & $.276 * *$ & .109 & $.333 * * *$ & .081 & .00574 & .066 & $.665^{* * *}$ & .162 \\
\hline Dynamic staff & $.106 * * *$ & .030 & -.003812 & .023 & -.00233 & .018 & .00455 & .045 \\
\hline $\begin{array}{l}\text { Good staff } \\
\text { development }\end{array}$ & -00299 & .066 & .000224 & .049 & -.00034 & .040 & -.00308 & .098 \\
\hline $\begin{array}{l}\text { Good work } \\
\text { environment }\end{array}$ & -.101 & .084 & $.147 *$ & .062 & $.229 * * *$ & .050 & $.275^{*}$ & .124 \\
\hline $\begin{array}{l}\text { Good Customer } \\
\text { focus }\end{array}$ & .00416 & .022 & $.00374 *$ & .017 & -.00083 & .013 & $.00701 *$ & .033 \\
\hline $\begin{array}{l}\text { Good subs \& } \\
\text { partner focus }\end{array}$ & $.101 * * * *$ & .026 & -.00234 & .019 & -.00018 & .016 & $.00761 *$ & .038 \\
\hline $\begin{array}{l}\text { Good community } \\
\text { linking }\end{array}$ & -.000582 & .042 & -.00264 & .031 & $.137 * * *$ & .025 & .107 & .062 \\
\hline $\begin{array}{l}\text { Image of a leading } \\
\text { firm }\end{array}$ & $.346^{* * * *}$ & .040 & $.269^{* * * *}$ & .030 & $.00498^{*}$ & .024 & $.666^{* * * *}$ & .059 \\
\hline $\begin{array}{l}\text { Stress } \\
\text { performance }\end{array}$ & .00759 & .052 & $.159 * * * *$ & .039 & .00155 & .032 & $.249 * * *$ & .078 \\
\hline US dummy & $.756^{*}$ & .323 & $1.613 * * *$ & .240 & $.690 * * *$ & .195 & $3.074 * * *$ & .479 \\
\hline UK dummy & .503 & .308 & $1.181 * * *$ & .229 & $.645 * * *$ & .185 & $2.332 * * *$ & .456 \\
\hline Constant & -.314 & .464 & -.323 & .345 & -.246 & .279 & -.884 & .688 \\
\hline $\begin{array}{l}\text { Adjusted } \\
\text { R-Square }\end{array}$ & .698 & & .696 & & .435 & & .810 & \\
\hline $\mathrm{N}=$ & 357 & & 357 & & 357 & & 357 & \\
\hline
\end{tabular}

\section{Examination of the Significant Stakeholder Factors}

The independent variables were constructed to capture the perceptions of our evaluators. All except one of the stakeholder related content factors had a significant impact on the dependent variables linked to corporate culture (dynamic, stable, friendly \& strong culture). An explanation that is consistent with our framework is that websites that were more explicit, self-conscious, and targeted in the projection of positive images and firm characteristics (figure 2) were the ones that effectively projected a positive corporate culture online. The discussion below of the significant content factors (table 2) provides some additional insights.

"Image of the Staff" is related to the perception of firms' employees and their capabilities. Positive images of dynamic, innovative and friendly staff reinforce the desired characteristics of the firm. This internal stakeholder factor can signal to external stakeholders that there is a strategic fit between employees and company vision. This factor had a significant impact on the perception of the firm as dynamic.

"Good work environment" is an internal stakeholder factor that reflects the climate of the work environment. Positive images and descriptions of the workplace send strong signals to potential employees and shows that the organization is responsive to internal stakeholders. This factor had a significant impact on the perception of firms as friendly and global companies. 
"Customer focus" is linked to the positive descriptions of product and service delivery. Words such as high quality, dependable, innovative, popular and convenient project the image of a corporation with a strong customer focus. This factor had a significant impact on the perception of the firms as strong culture and global organizations.

The "Subsidiary \& partner focus" shows how firms interact with and value their cooperative network relationships. Since these external stakeholders can have a direct impact on the organization's ability to deliver products or services, it is important for firms to project strong, flexible and positive relationships. This factor had a significant impact on the perception of the firms as dynamic, strong culture organizations.

"Good community linking" highlights the firm's community related activities that go beyond a single focus on transactions in goods and services. The website points out that the firm is not only serving the community but actively interacting with community stakeholders. The firm-community relationship is often presented as an important aspect of the organization's mission. This factor had a significant impact on the perception of the firm as having a friendly culture.

"Image of a leading firm" emphasizes the position of the firm as a market leader. This perception is important for investors, customers, the community and even competitors. By stressing its dominant position and strong institutional ties, the firm is usually viewed as a legitimate organization with distinct competencies and capabilities. Prestige and power are important images in many societies and can engender more trust from external stakeholders. This factor had a strong and significant impact on all the corporate culture characteristics.

"Stressing Firm Performance" is linked to the firm's pride in performance and vision for the future. By highlighting the desire to excel and grow, external stakeholders view the organization as responsive to market demands. A more responsive firm is also preferred by actual or potential investors who might inject in or increases resources to the firm. This factor had a significant impact on the view of the firm as a strong culture organization.

As for the "US/UK dummy variables", these variables show how American and British firms compare with Japanese firms (reference category) in projecting corporate culture characteristics online. For dynamic culture, only American firms were significantly better than Japanese firms at projecting that characteristic. For all the other corporate web culture characteristics, both the American and British firms did a significantly better job at projecting their culture online.

"Good web organization" is a non-content factor that had a strong and significant impact on most of the corporate web culture characteristics. It is our view that the effective use of web design can drive the perception of a site being well organized. Since the manner in which websites are designed can vary significantly across national environments, it is more important and analytically helpful to focus on the perceptions of the outcome. It is our view that it is the individuals form the same cultural environment who are best able to judge if a website is well organized. This factor had a significant impact on most of the projected corporate web characteristics.

"Effective web tools" is linked to web design and the interaction capability of websites. This includes the use of colors, photos and the navigation features of the website. This is the only non-stakeholder factor in our model. It had a significant impact on three of the four corporate cultural characteristics. We used a subjective evaluation to measure this factor and

Our framework strongly stressed the importance of a communication orientation to stakeholder related content. The independent evaluators rated the sites for their ability to project the firms' image as being dynamic, global, and friendly. In most cases, the clear and positive descriptions of each firm's stakeholder related information on the websites appear to have successfully projected corporate cultural characteristics. The high level adjusted Rsquares indicate that our regression models did a good job of explaining the corporate culture projection phenomenon.

\section{CONCLUSION}

In terms of building a website culture, internet strategy can be divided into web organization or web 
content related factors. We considered web design and web tools as the main determinants of how organized a website appeared. In fact, many studies have provided ideas on how to coordinate web design and web tools to effectively organize a website. (Bauer and Scharl 2000; Huizingh 2000; Katerattanakul 2002).

However, in contrast to the many studies on web organization, fewer studies examined how the structuring of web content could have a strategic purpose. In this paper, we showed how web content could be used to manage impressions, signal firm capabilities and target stakeholders. The strategy of structuring web content is at the heart of the AIPD stakeholder approach. It is an approach that can give structure to the massive amounts of information that can potentially populate a website.

There are a number of implications for international firms. First, firms should realize that creating a virtual identity must involve methods that allow for the development, manipulation and accumulation of positive descriptions, images and perceptions. Consequently, companies should move beyond the preoccupation with only transaction-centered web design and technology to a more strategic view of web content. In doing so, firms can focus on creating a more consistent image and experience for their stakeholders worldwide. A consistent web culture could also serve to develop trust in the firm's capabilities. Finally, by targeting stakeholder concerns, firms can position themselves as responsive to the domestic and international market environment.

In terms of cross border studies, it is clear that although the AIPD stakeholder approach can illustrate how firms are projecting corporate cultural characteristics, there are significant variations in the extent to which there is an effort by local firms to be explicit, self-conscious and targeted. However, despite the differences, an AIPD orientation is the best approach for international firms that may be not be well known in various foreign environments. In a sense, building a virtual corporate identity becomes an important strategic mode of entry into different marketing and social environments.

One area which could have been more thoroughly explored is the possible interaction between the website design and the structuring of web content. There is evidence that in some environments, a premium is placed on the manner in which particular color schemes, animation figures, and web tools serve to create a certain web climate (Denison 1996; Fink and Laupase 2000; Tang 2001). Depending on the national environment, it is possible that these web organization factors could boost or moderate the impact of the stakeholder related web content. This is an area to be covered in subsequent studies of web strategy and culture.

\section{AUTHOR INFORMATION}

Roblyn Simeon is a professor of international business at San Francisco State University. He has taught a wide range of courses related to international business. His main areas of research include internet marketing strategies, popular culture dynamics, comparative business strategies, organizational behavior, career management and emerging market strategies. In addition to having been involved in many executive training and management consulting projects, Professor Simeon has also worked on Wall Street and in Tokyo as a financial and securities analyst. He is fluent in five languages and has lived in and traveled extensively in Europe, South America, and Asia.

\section{REFERENCES}

1. $\quad$ Adair, W. L., T. Okumura, et al. (2001). "Negotiation behavior when cultures collide: The United States and Japan." Journal of Applied Psychology 86(3): 371-385.

2. Aladwani, A. M. and P. C. Palvia (2002). "Developing and validating an instrument for measuring userperceived web quality." Information \& Management 39(6): 467-476.

3. AlbersMiller, N. D. and B. D. Gelb (1996). "Business advertising: Appeals as a mirror of cultural dimensions: A study of eleven countries." Journal of Advertising 25(4): 57-70.

4. Argyris, C. S., D. (1978). Organizational Learning: a Theory of Action Perspective. Reading, MA., Addison-Wesley.

5. $\quad$ Bauer, C. and A. Scharl (2000). "Quantitative evaluation of Website content and structure." Library Computing 19(3-4): 134-146.

6. $\quad$ Betts, M. (1995). "Privacy fades for Web visitors." Computerworld 29: 162. 
7. Bloor, G. (1994). "Understanding Professional Culture in Organizational Context." Organization Studies 15(2): 275-295.

8. $\quad$ Borsook, P. (1995). "Demolition man." Network World 12: SS26-SS30.

9. $\quad$ Cairncross, F. (2000). "Survey: E-management--Talking to each other." Economist 357: S10-S16.

10. Chabrow, E. (2000). "Who calls the shots? A new management matrix emerges." Informationweek: 72.

11. Croft, B. (1995). "Opening windows to the world." Communication World 12: 16-19.

12. Cunliffe, D., H. Jones, et al. (2002). "Information architecture for bilingual Websites." Journal of the American Society for Information Science and Technology 53(10): 866-873.

13. Denison, D. (1990). Corporate Culture and Organizational Effectiveness. New York, N.Y., Wiley.

14. Denison, D. R. (1996). "What is the difference between organizational culture and organizational climate? A native's point of view on a decade of paradigm wars." Academy of Management Review 21(3): 619-654.

15. Denison, D. R. and A. K. Mishra (1995). "Toward a Theory of Organizational Culture and Effectiveness." Organization Science 6(2): 204-223.

16. Deshpande, R., J. U. Farley, et al. (2000). "Triad lessons: Generalizing results on high performance firms in five business-to-business markets." International Journal of Research in Marketing 17(4): 353-362.

17. Dunkerley, K. J. and W. P. Robinson (2002). "Similarities and differences in perceptions and evaluations of the communication styles of American and British mangers." Journal of Language and Social Psychology 21(4): 393-409.

18. Evans, J. and F. T. Mavondo (2002). "Psychic distance and organizational performance: An empirical examination of international retailing operations." Journal of International Business Studies 33(3): 515532.

19. Fink, D. and R. Laupase (2000). "Perceptions of Website design characteristics: a Malaysian/Australian comparison." Internet Research-Electronic Networking Applications and Policy 10(1): 44-55.

20. $\quad$ Fitzgerald, T. (1988). "Can change in organizational culture really be managed?" Organizational Dynamics 17: 5-15.

21. Gaffin, A. (1994). "Businesses get schooled in "culture" of the Internet." Network World 11: 1,62.

22. Gordon, G. G. and N. Ditomaso (1992). "Predicting Corporate Performance from Organizational Culture." Journal of Management Studies 29(6): 783-798.

23. Gray, L. (1999). "Ohio Savings Bank leapfrogs big competitors with Internet leadership." Journal of Retail Banking Services 21: 15-18.

24. Grochow, J. M. (1996). "The Corporate Intranet: Online in a Big Way." Data Communications 25: 33-34.

25. Gudykunst, W. B. (1998). "Individualistic and collectivistic perspectives on communication: An introduction." International Journal of Intercultural Relations 22(2): 107-134.

26. Gudykunst, W. B., Y. Matsumoto, et al. (1996). "The influence of cultural individualism-collectivism, self construals, and individual values on communication styles across cultures." Human Communication Research 22(4): 510-543.

27. Harris, L. C. and E. Ogbonna (2002). "The unintended consequences of culture interventions: A study of unexpected outcomes." British Journal of Management 13(1): 31-49.

28. Hernon, P. (1998). "Government on the Web: A comparison between the United States and New Zealand." Government Information Quarterly 15(4): 419-443.

29. Hibbard, J. (1998). "Cultural breakthrough." Informationweek: 44-55.

30. Hofstede, G. (1998). "Attitudes, values and organizational culture: Disentangling the concepts." Organization Studies 19(3): 477-493.

31. Homburg, C. and C. Pflesser (2000). "A multiple-layer model of market-oriented organizational culture: Measurement issues and performance outcomes." Journal of Marketing Research 37(4): 449-462.

32. Hornick, L. (1998). "Shaping perceptions, influencing stakeholders, and winning respect." Communication World 15: 52-54.

33. Huizingh, E. (2000). "The content and design of Websites: an empirical study." Information \& Management 37(3): 123-134.

34. Kabanoff, B. and J. P. Daly (2000). "Values espoused by Australian and US organisations." Applied Psychology-an International Review-Psychologie Appliquee-Revue Internationale 49(2): 284-314.

35. Katerattanakul, P. (2002). "Framework of effective Website design for business-to-consumer Internet commerce." Infor 40(1): 57-70. 
36. Knights, D. a. W., H. (1987). "Organizational culture as management strategy: a critique and illustration." International Studies of Management and Organization 13: 40-63.

37. Kuchinskas, S. (1999). "Victoria's Secret: Best marketing event." Brandweek 40: IQ48.

38. Lam, K.-Y. (1997). Ethnic Cyber-Communities. 8th ACRL Conference, Nashville, Tennessee, National Association of College \& Research Libraries.

39. Lewis, C. (Oct/Nov 2000). "New kid on the block: Launching your business and your brand successfully in an E-based economy." Executive Speeches 15: 16-22.

40. Marcus, A. (2003). Are you cultured? Newarchitect.com: 28-34.

41. Marken, G. A. (1996). "The power of the Internet isn't for every organization." Public Relations Quarterly 41: 47-48.

42. Ogbonna, E. and L. C. Harris (2000). "Leadership style, organizational culture and performance: empirical evidence from UK companies." International Journal of Human Resource Management 11(4): 766-788.

43. $\quad$ Pack, T. (Jun 2001). "Good karma: Plastic.com's community-driven content model." Econtent 24: 54-55.

44. Patrick, J. R. (1997). "Get connected." Journal for Quality \& Participation 20: 76-81.

45. Pettigrew, A. (1979). "On studying organizational cultures." Administrative Science Quarterly 24: $570-581$.

46. Ranganathan, C. and S. Ganapathy (2002). "Key dimensions of business-to-consumer websites." Information \& Management 39(6): 457-465.

47. $\quad$ Robbins, S. S. and A. C. Stylianou (2001). "A study of cultural differences in global corporate Websites." Journal of Computer Information Systems 42(2): 3-9.

48. Robbins, S. S. and A. C. Stylianou (2003). "Global corporate websites: an empirical investigation of content and design." Information \& Management 40(3): 205-212.

49. Schein, E. (1991). What is culture? in Reframing Organizational Culture. L. M. P. Frost, M. Louis, C. Lundberg and J. Martin (eds). Newbury Park, CA., Sage: 243-253.

50. Schultz, M. (1994). On Studying Organizational Cultures. Berlin, Germany., De Gruyter.

51. Scott, S. G. and V. R. Lane (2000). "A stakeholder approach to organizational identity." Academy of Management Review 25(1): 43-62.

52. Simeon, R. (1999). "Evaluating domestic and international web-site strategies." Internet Research 9(4): 297-308.

53. Simeon, R. (2001). "Evaluating the branding potential of Websites across borders." Marketing Intelligence \& Planning 19(6): 418-424.

54. Steenkamp, A. B. E. (2001). "The role of national culture in international marketing research." International Marketing Review 18(1): 30-44.

55. Tang, R. (2001). Developing multilingual academic websites: A study of Chinese university web design for the Chinese and the English versions. Asist 2001: Proceedings of the 64th Asist Annual Meeting, Vol 38, 2001. Medford, INFORMATION TODAY INC. 38: 458-471.

56. Taylor, M. (1997). "Intranets--a new technology changes all the rules." Telecommunications (Americas Edition) 31: 39-40.

57. Violino, B. (2000). "Lesson From E-Business Leaders: Results Matter -- InternetWeek 100 companies are generating impressive returns on their Net investments." Internetweek: 31-34.

58. $\quad$ Williams, R. L. (1999). "On-line communities." Executive Excellence 16: 7.

59. Zhou, Z. and K. Nakamoto (2001). Price perceptions: A cross-national study between American and Chinese young consumers. Advances in Consumer Research, Vol Xxvii. Provo, ASSOC CONSUMER RESEARCH. 28: 161-168.

60. Zimmerman, C. (2000). "Banking on a Culture Change -- Harrison Tempest 'Webified' ABN Amro before creating Internet links with partners." Internetweek: G179-180. 


\section{APPENDIX}

Table 3: The Major Components of the Website Culture Evaluation Framework

\begin{tabular}{|c|c|c|c|c|c|c|c|c|c|}
\hline \multicolumn{10}{|c|}{ I. Website Organization: Numbers 4-10 } \\
\hline \multicolumn{10}{|c|}{ For Numbers 4-10, input $0=$ absent and $1=$ present } \\
\hline & & & Search & Many jobs & Can submit & Links to & Links to & Photos of & Profile of \\
\hline Company & Web location & Country & Engine at & Listed & resume & other co. & Affiliates or & Employees & Top Execs \\
\hline Name & http://URL & Location & the site? & oline? & online? & locations? & partners? & at website? & online? \\
\hline 1 & $\underline{\mathbf{2}}$ & $\underline{\mathbf{3}}$ & 4 & $\underline{\mathbf{5}}$ & $\underline{6}$ & $\underline{7}$ & $\underline{\mathbf{8}}$ & 9 & $\underline{10}$ \\
\hline
\end{tabular}

\begin{tabular}{|c|c|c|c|c|c|c|}
\hline \multicolumn{7}{|c|}{ II. Customer Culture: Numbers 11- 16} \\
\hline \multicolumn{7}{|c|}{ Input on 1-5 scale, Extent to which the company writes about providing } \\
\hline Unique & innovative & & Dependable & Good & Quick \& & Popular \\
\hline products/ & Products/ & Excellent & Services/ & customer & convenient & Services/ \\
\hline Services & Services & Quality & Products & support & Service & products \\
\hline$\underline{11}$ & $\underline{12}$ & 1 & $\underline{\mathbf{3}}$ & 14 & $\underline{15}$ & $\underline{16}$ \\
\hline
\end{tabular}

\begin{tabular}{|c|c|c|c|}
\hline \multicolumn{4}{|c|}{ III. Culture linked to Partners: Numbers 17-20 } \\
\hline \multicolumn{3}{|c|}{ Input on 1-5 scale, Extent to which the company writes about having } \\
\hline strong & Extensive & Flexible & Cooperative \\
\hline partnerships & networks & alliances & Relations \\
\hline$\underline{17}$ & $\underline{\mathbf{1 8}}$ & $\underline{\mathbf{1 9}}$ & $\underline{\mathbf{0}}$ \\
\hline
\end{tabular}

\begin{tabular}{|c|c|c|c|c|c|c|c|c|c|c|}
\hline \multicolumn{10}{|c|}{ IV. Employee/Staff/Management Culture: Numbers 21-31 } \\
\hline \multicolumn{10}{|c|}{ Input on 1-5 scale, Extent to which the company writes about having or seeking } \\
\hline Exciting & Creative \& & Staff with & dependable & Good & group & Excellent & A fun & Good & Internation- & investment \\
\hline Career & innovative & initiative \& & hard-working & problem & oriented & leadership & or dynamic & staff & ally oriented & in staff \\
\hline Opportunities & employees & judgment & staff & solvers & workplace & skills & workplace & Diversity & Employees & development \\
\hline$\underline{\mathbf{2 1}}$ & $\underline{\mathbf{2 2}}$ & $\underline{\mathbf{2 3}}$ & $\underline{\mathbf{2 4}}$ & $\underline{\mathbf{2 5}}$ & $\underline{\mathbf{2 6}}$ & $\underline{\mathbf{2 7}}$ & $\underline{\mathbf{2 8}}$ & $\underline{\mathbf{2 9}}$ & $\underline{\mathbf{3 0}}$ & $\underline{\mathbf{3 1}}$ \\
\hline
\end{tabular}

\begin{tabular}{|c|c|c|c|c|c|c|c|}
\hline \multicolumn{7}{|c|}{ V. Investors and Company Culture: Numbers 32-39 } \\
\hline \multicolumn{7}{|c|}{ Input on 1-5 scale, Extent to which site information supports the statements below } \\
\hline Firm is a & Co. is & Co. is a & Extensive & Co. Vision & Co. using & Co. wants & high staff \\
\hline market & proud of & global & Co. history & Is to excel & responsive & to serve & Community \\
\hline leader & performance & company & online & \& grow & strategies & community & Interaction \\
\hline$\underline{\mathbf{3 2}}$ & $\underline{\mathbf{3 3}}$ & $\underline{\mathbf{3 4}}$ & $\underline{\mathbf{3 5}}$ & $\underline{\mathbf{3 6}}$ & $\underline{\mathbf{3 7}}$ & $\underline{\mathbf{3 8}}$ & $\underline{\mathbf{3 9}}$ \\
\hline
\end{tabular}

\begin{tabular}{|c|c|c|c|c|c|c|c|c|}
\hline \multicolumn{9}{|c|}{ VI. Website \& Company Evaluation: Numbers 40-47 } \\
\hline \multicolumn{9}{|c|}{ On a scale from $1-5$, indicate level of agreement with company \& website characteristics } \\
\hline Well & Site clearly & & & & & & & \\
\hline Organized & Shows & Co. is & Co. is & Co. is & Co. is & Co. is a & Co. is & \\
\hline Web-site & co. culture & innovative & Flexible & Global & Stable & Leader & Friendly & \\
\hline 40 & 41 & 42 & 43 & 44 & 45 & 46 & 47 & \\
\hline
\end{tabular}


Table 4: Scales \& Reliability Analysis

\begin{tabular}{|l|c|c|c|}
\hline \multicolumn{1}{|c|}{ Scale Name } & Number of Variables & Variables included in scale++ & Cronbach Alpha \\
\hline Good Web tools & 6 & $4,5,6,7,8,9$ & .60 \\
\hline Dynamic Staff & 7 & $22,23,24,25,27,29,30$ & .91 \\
\hline Good Staff Development & 2 & 21,31 & .74 \\
\hline Good Work Environment & 2 & 26,28 & .81 \\
\hline Good Customer Focus & 7 & $11,12,13,13 \mathrm{~B}, 14,15,16$ & .84 \\
\hline Sub \& Partner Focus & 4 & $17,18,19,20$ & .89 \\
\hline Good Community linking & 2 & 38,39 & .90 \\
\hline Image of a leading firm & 3 & $32,34,35$ & .63 \\
\hline Performance focus firm & 3 & $33,36,37$ & .71 \\
\hline Dynamic Firm & 3 & $42,43,44$ & .72 \\
\hline Stable Firm & 2 & 45,46 & .82 \\
\hline Comprehensive Culture & 6 & $42,43,44,45,46,47$ & .84 \\
\hline
\end{tabular}

++ See table 3 for corresponding items and variables 
Table 5: Sample of the Firms Used in Data for Website Information

\begin{tabular}{|c|c|c|}
\hline American Firms & British Firms & Japanese Firms \\
\hline $\begin{array}{l}\text { 3M } \\
\text { Abercrombie \& Fitch } \\
\text { Acura } \\
\text { Adobe Sytems } \\
\text { Aegis } \\
\text { Airborne Express } \\
\text { Albertsons } \\
\text { amazon.com } \\
\text { America Online (AOL) } \\
\text { Anheuser-Busch } \\
\text { Anheuser-Busch Co. } \\
\text { AOL } \\
\text { Apllied Materials } \\
\text { Apple } \\
\text { AT\&T } \\
\text { AutoDesk } \\
\text { Avon } \\
\text { Bank Of America } \\
\text { Bank One } \\
\text { BE, Inc. } \\
\text { Bechtel } \\
\text { Ben \& Jerry's } \\
\text { Biospherics } \\
\text { Boeing } \\
\text { Boston Consulting Group } \\
\text { Brightware } \\
\text { Cadillac } \\
\text { California Bank Trust } \\
\text { CETCO } \\
\text { Chevron } \\
\text { Chipshot.com } \\
\text { Chrysler } \\
\text { Cingular } \\
\text { Circuit City } \\
\text { Cisco Systems } \\
\text { Coca-Cola } \\
\text { ConStat } \\
\text { Coors Brewing Company } \\
\text { Critical Path } \\
\text { Dell Computer Corporation } \\
\text { DELTA AIR LINES } \\
\text { Disney Company } \\
\text { Display Technologies } \\
\text { Dreyer's Grand Ice Cream }\end{array}$ & $\begin{array}{l}\text { ABF } \\
\text { Adams } \\
\text { AdVal Group plc } \\
\text { AEA Technology } \\
\text { Aegis Group } \\
\text { Airtours } \\
\text { Allied Domecq PLC } \\
\text { Alphameric plc } \\
\text { Amersham International } \\
\text { Amstrad } \\
\text { Amvescap } \\
\text { Apolent } \\
\text { Arcadia Group plc } \\
\text { Aston Martin } \\
\text { Astrazeneca } \\
\text { ATA Group } \\
\text { ATOC } \\
\text { Baillie Gifford } \\
\text { Balfour Beatty plc } \\
\text { Bentalls } \\
\text { Bioglan Pharmacy } \\
\text { Boots Opticians Ltd } \\
\text { British Airways } \\
\text { British American Tobacco } \\
\text { British Vita } \\
\text { Cable \& Wireless } \\
\text { Cadbury Schweppes } \\
\text { Candover } \\
\text { Caradon Hyroflex } \\
\text { Carillion Communications } \\
\text { Carlsberg } \\
\text { Claremont } \\
\text { Cradley Print plc } \\
\text { Croda International plc } \\
\text { Cummins Diesel UK } \\
\text { Daily Mail \& General Trust } \\
\text { Dairy Crest } \\
\text { DANA Petroleum } \\
\text { DANKA Bus. Systems } \\
\text { De La Rue International Ltd. } \\
\text { Diageo plc } \\
\text { DIXON MOTORS } \\
\text { Dixons Group PLC } \\
\text { Dreyfus, Louis \& Co. } \\
\text { Ec soft Group } \\
\text { A }\end{array}$ & $\begin{array}{l}\text { THE DAI-ICHI MUTUAL LIFE } \\
\text { INSURANCE COMPANY } \\
\text { THE TOKIO MARINE AND FIRE } \\
\text { INSURANCE CO., LTD. } \\
\text { Yasuda Fire and marine insurance } \\
\text { corporation } \\
\text { THE SUMITOMO MARINE \& } \\
\text { FIRE INSURANCE CO.,LTD. } \\
\text { The Fuji bank Limited. } \\
\text { The Bank of Tokyo-Mitsubishi,Ltd. } \\
\text { The Sanwa Bank,Limited. } \\
\text { Sumitomo Mitsui Banking } \\
\text { Corporation. } \\
\text { Nomura } \\
\text { The Nikko Securities Co., Ltd. } \\
\text { UC Card Co., Ltd. } \\
\text { JCB Co., Ltd. } \\
\text { Toyota Motor Corporation } \\
\text { NISSAN MOTOR CO., LTD. } \\
\text { Mazda Motor Corporation } \\
\text { Mitsubishi Motors Corporation } \\
\text { Honda Motor Co.,Lt } \\
\text { Toshiba Corporation } \\
\text { Nihon HP } \\
\text { CANON INC. } \\
\text { Hitachi, Ltd. } \\
\text { Seiko Epson corpration } \\
\text { NEC Corporation } \\
\text { Matsushita Electric Industrial Co., } \\
\text { Ltd. } \\
\text { Pioneer Corporation } \\
\text { FUJITSU } \\
\text { Sharp Corporation. } \\
\text { Sony AND } \\
\text { ALPS ELECTRIC CO.,LTD. } \\
\text { VICTOR COMPANY OF JAPAN, } \\
\text { LIMITED } \\
\text { Oki Electric Industry Co.,Ltd. } \\
\text { CITIZEN WATCH CO.,LTD. } \\
\text { Fuji Xerox, Co. Ltd. } \\
\text { NIPPON TELEGRAPH } \\
\text { TELEPHONE CORPORATION } \\
\text { Nikon Corporation } \\
\text { Minolta Co., Ltd. } \\
\text { HOYA CORPORATION } \\
\text { TERUMO } \\
\text { CORPORATION,JAPAN } \\
\text { OMRON Corporation }\end{array}$ \\
\hline
\end{tabular}


NOTES 